\title{
Why Governments Prefer Spatially Segregated Settlement Sites for Urban Refugees
}

\author{
Gaim Kibreab
}

\section{Abstract}

The urbanization of Africa has been recent, rapid and notably disimllar from the pattern of urbanization that occured previously in Europe. Significantly, the urbanization of Africa has occured in the absence of structural transformation. Within this reality, refugees are viewed by African host governments as exacerbating the problems of urbanization and are most often located in government-designated and spatially segregated sites refugee camps or settlements. Often in defiance of such policies, most refugees with urban backgrounds tend to congregate in urban centres. The case study of Sudan illustrates that even where the stay of certain refugees in urban areas may be formally regularised by governments there are nonetheless identifiable common patterns and problems arising out of and causing the spatial segregation of refugees away from urban centres. It is argued that the underlying reality of urbanization in Africa plus the protracted problems for governments created by urbanisation generally and cross-border ethnic solidarity in the case of many refugee movements in Africa, shape current hostile refugee policies towards urban refugees.

\section{Résumé}

L'urbanisation de l'Afrique est de date récente. Elle s'est faite de façon rapide et a suivi un parcours particulièrement différent de celui emprunté par l'urbanisation précédente de l'Europe. De manière significative, l'urbanisation de l'Afrique s'est produite en l'absence d'une transformation structurelle. Avec cette réalité comme toile de fond, les réfugiés sont perçus par les gouver- nements hôtes des pays d'Afrique comme aggravant les problèmes d'urbanisation, et ils sont le plus souvent installés dans des lieux spécialement désignés par les gouvernements et spatialement séparés - notamment des camps de réfugiés ou des zones d'installations.

Souvent en faisant fi de telles politiques, la plupart des réfugiés issus des milieux urbains tendent à se rassembler dans les centres urbains. L'étude de cas du Soudan démontre que même là où des gouvernements arrivent à sanctionner le séjour de certains réfugiés en milieux urbains, on peut néanmoins identifier des tendances communes et des problèmes qui résultent de, et provoquent, la ségrégation spatiale des réfugiés loin des centres urbains.

L'article soutient que la réalité sous-jacente de l'urbanisation en Afrique, ajoutée aux problèmes à n'en pas finir confrontant les gouvernements et engendrés, d'une part par l'urbanisation en général, et de l'autre par la solidarité ethnique transfrontalière dans le cas de beaucoup de mouvements de réfugiés en Afrique, tout cela pris ensemble, façonne les politiques actuelles relatives aux réfugiés qui sont hostiles aux réfugiés urbains.

\section{Introduction and Statement of the Problem}

7 he question of urban refugees should be placed in the context of the rapid process of urbanization experienced by most African countries. What is peculiar about the process of urbanization in this region is that it is taking place in the absence of structural transformation. ${ }^{1}$ In the West, rural-urban migration took place in the eighteenth and nineteenth centuries in the context of massive process of structural transformation reflected in technologi- 
cal innovation, industrialization, and shrinkage of the primary sector-agriculture. As a result, those who were separated from their means of production were easily absorbed in manufacturing and later in the expanding service sector.

In much of Africa, however, the manufacturing sector is very small and its capacity of absorption is quite limited. The manufacturing sector has been experiencing further constriction due to macro-economic policy reforms introduced in connection with structural adjustment programs. Many adjusting economies in sub-Saharan Africa have been experiencing a process of de-industrialization due to inability to compete with economies that enjoy technological comparative advantages. In most sub-Saharan African countries, the primary sector-agriculture-still remains a dominant economic activity. However, the performance of the agricultural sector has been prejudicially affected by adverse weather conditions, lack of productivity-enhancing modern technological inputs, and high population pressure. Horizontal expansion of commercial agriculture which takes place in the absence of well-developed policy and institutional framework and enforcement capability has led not only to loss of traditional resource rights but also to degradation of productive capability of renewable resources. In the countries that have been experiencing expansion of commercial agriculture, the property rights regimes are so inauspicious that they provide no adequate protection against encroachment by commercial interests. ${ }^{2}$ In most cases, those who are squeezed out in the process or separated from the means of production are left with no alternative but to migrate to urban areas in search of sources of livelihoods. Sub-Saharan Africa has been experiencing rapid urbanization in the context of lack of protection of pastoralist and peasant land and resource rights. The poor performance and the low capacity of absorption of the agricultural sector is also substantially exacerbated, on the one hand, by the excessive subsidies paid to farmers in the European Union and North America and, on the other, by the restrictions imposed by the European Union and the US government on imports of primary and processed agricultural products from developing countries, including Africa. Governments in the EU and the US preach liberalism but in reality their markets are inaccessible because they are protected. This policy has had a detrimental impact on the economies of African countries and has resulted not only in the economic stagnation of the agricultural and the manufacturing sectors but also in squalor and poverty in the urban areas where there are large concentrations of unrecognized refugees. The hostility of host governments and, to some extent, host populations towards them cannot be understood in isolation from what goes on in the international arena.
In sub-Saharan Africa, rural-urban migrants invariably end up in the saturated informal sector where competition is fierce. The informal sector is the only conceivable source of livelihood for: (i) retrenched public sector employees; (ii) workers laid off from the private sector due to rationalization/restructuring or de-industrialization; (iii) new job seekers; and (iv) those who need to supplement their meagre incomes. Some of these are consequences of structural adjustment programs. In the past, the informal sector was considered "spongy," reflected in an "unlimited" capacity of absorption. These days, there are no analysts who believe that the capacity of the informal sector to absorb new entrants is unlimited.

The other factor that is contributing to rapid urbanization in Africa is the educational system, which is highly elitist and inevitably detaches students from their particular socio-cultural environments. Most of the curricula taught in African schools are designed to prepare students for employment in the modern urban sector. Unfortunately, this sector is stagnant for reasons explained above, and its capacity to absorb additional labour is either limited or non-existent. The millions of students who complete secondary education often leave school without any vocational skills and are hence unemployable. Those from rural areas often seek an escape from rural life, instead ending up in urban slums, and try to eke out a meagre existence in the informal sector. Though the informal sector is dynamic, its capacity of absorption is not unlimited. In most African countries, it is stretched to a breaking point.

The fact that this rapid urbanization is taking place in the absence of structural transformation also means that the states are unable to generate enough revenues from taxes to invest in the social and physical infrastructures to cope with increased demand. Thus, in most of sub-Saharan Africa, the infrastructures in urban areas are either weak or are on the verge of collapse. This can also exacerbate the HIV/AIDS pandemic due to shortages of housing, sanitary facilities, health services, and educational opportunities. When diverse groups inhabit slum areas in cities and individuals originating from different ethnic, religious, and geographical origins and different cultural backgrounds intermingle, the informal institutional rules and social norms that previously regulated their sexual and other social behaviours tend to weaken if not break down. This creates fertile ground for the spread of HIV/AIDS and other sexually transmitted diseases.

\section{Urban Refugees: Unwelcome Guests}

In Africa as elsewhere in developing societies, governments loathe the presence of refugees in urban areas. ${ }^{3}$ This is because they see the presence of refugees as a factor that 
exacerbates the urban condition. Hence they prefer to place all refugees regardless of their occupational, educational, and experiential backgrounds in government-designated and spatially segregated sites-refugee camps or settlements. More often than not, these sites are devoid of freedom of movement and residence. ${ }^{4}$ Some governments also apply draconian measures to control the behaviour and political activities of refugees in such sites. ${ }^{5}$ Whenever refugees want to leave such sites they are required to seek permission. ${ }^{6}$ Nearly all African host governments do not formally recognize the rights of refugees to settle in urban areas. ${ }^{7}$ Understandably, therefore, most refugees with urban backgrounds are opposed to living in refugee camps or settlements where no employment opportunities, amenities, and freedom of movement exist. Thus, most refugees with urban backgrounds tend to congregate in urban centres, defying host governments' policies. As a result, they are in most cases treated in a manner that violates their basic human rights. ${ }^{8}$

As we shall see in a brief case study of Sudan, there may be some cases of refugee populations whose stay in urban areas may be formally regularized by governments, but these are exceptions. Nevertheless, notwithstanding hostile government policies, in all refugee-hosting countries in sub-Saharan Africa, there are tens of thousands of refugees who reside in urban areas illegally. This is because governments are either unable to enforce their own laws and policies or refugees subvert the restrictions by developing complex strategies, including adoption of fictive identities, to pass as citizens. ${ }^{9}$ Given the artificial construction of many African borders which were established by bisecting communities, it is not easy to distinguish between citizens and non-citizens who often share identical structural traits.

\section{The Rationale of Placing Refugee in Spatially Segregated Sites}

Even though the rationales discussed in what follows are based on the experience of sub-Saharan Africa, they are relevant to all developing countries. ${ }^{10}$ Though the rationales that underpin different host governments' policies on urban refugees may be varied, it is argued here that there are identifiable common patterns that characterize most governments' responses to urban refugees. These include:

1. prevention of integration of refugees into host societies;

2. minimization of actual or perceived risk to national security;

3. prevention of refugee competition with nationals for employment, self-employment, resources, and services;

4. aversion to ethnic imbalance in border areas;
5. shifting of responsibility in meeting refugees' needs to the international donor community indefinitely, including UNHCR;

6. creation of an opportunity to develop previously neglected remote areas; and

7. prevention or minimization of societal insecurity.

Each of these factors is discussed in what follows briefly.

\section{Prevention of Integration of Refugees into Host Societies} The three conventional solutions to the problem of refugees are enshrined in the Statute of the UNHCR. Paragraph 1 of the Statute states:

The United Nations Commissioner for Refugees, acting under the authority of the General Assembly, shall assume the function of providing international protection, under the auspices of the United Nations to refugees who fall within the scope of the present Statue and of seeking permanent solutions for the problem of refugees by assisting Governments and, subject to the approval of the Governments concerned, private organisations to facilitate the voluntary repatriation of such refugees, or their assimilation within new national communities. ${ }^{11}$

It is important to point out, however, that in all African countries - and this is true in all developing countries ${ }^{12}$ refugees are accepted as temporary guests, notwithstanding the fact that the United Nations in co-operation with governments is required to seek permanent solutions to the problem of refugees by integrating the latter into receiving communities. In the developing countries, settlement in first countries of asylum does not provide a permanent solution to the refugee problem. This is true regardless of the length of their stay in countries of asylum. Refugee status is granted in anticipation that they would return home subsequent to the elimination of the factors that prompt them to flee. Thus, most host government policies are designed to prevent rather than to promote integration of refugees into host societies. For example, despite long-standing open door policies ${ }^{13}$ in Tanzania, Uganda, and Sudan, their reception and settlement strategies are designed to prevent rather than to promote integration of refugees. Treatment of refugees in these countries is formally based on the general principles of international conventions, mainly that asylum is a peaceful and humanitarian act; that voluntary repatriation is the ideal and most durable solution to the refugee problem; and that in the absence of any foreseeable prospects for repatriation, refugees are to be settled away from border areas with the aim of helping them to become self-supporting. Self-settlement is regarded by all sub-Saharan African countries as an unacceptable option. ${ }^{14}$ The single most important reason 
why the consecutive governments in these countries reject self-settlement of refugees is, inter alia, to prevent refugees from integrating into the host communities.

This does not suggest, however, that there are no refugees that self-settle outside of government designated sites by defying host government policies. ${ }^{15}$ This does not also suggest that there are no African refugees who become integrated into host societies by disregarding government policies. There are refugee communities that integrate themselves into host societies by relying on pre-existing historical, ethnic, language, and faith-based informal social networks. For example, notwithstanding the fact that the factors that produced pre-independence Eritrean refugees have indisputably ceased when the country achieved its independence, a substantial proportion of the refugees in Kassala and Port Sudan towns have stayed put. These are invariably people who share common ethnicity, religion, language, and way of life with the local residents. ${ }^{16}$

For example, the government of Sudan enacted its own national legislation to this end, known as the Regulation of Asylum Act, 1974. The Asylum Act lays down the principles upon which the country's refugee policies and practices are based. There are some fundamental restrictions which are designed to perpetuate rather than to end refugee status. For example, refugees are prohibited from owning land and immovable property. ${ }^{17}$ Non-compliance is punishable with imprisonment not exceeding one year. ${ }^{18}$ The raison d'être of the limitation on freedom of movement and residence is prevention of integration of refugees into the host societies because they are accepted as temporary guests until the factors that prompt their displacement are eliminated. ${ }^{19}$ For example, the late Dr. Ahmed Karadawi, who was an assistant commissioner for refugees in the Ministry of Interior, said,

As most of the refugee situations in the Sudan have not developed because of any deliberate intention either on the part of the refugees or on the part of the government, how realistic is the approach that aims at helping the refuges to settle permanently in the Sudan and become Sudanese? The strategy of what is called 'integration' by the aid agencies is a European import oblivious to the local processes that have brought refugees into the Sudan. ${ }^{20}$

Karadawi could not be regarded as xenophobic or refugeeunfriendly by any standard..$^{21}$ This clearly demonstrates that Sudan's refugee policies are designed to perpetuate rather than to end refugee status. This was further amplified by the Commissioner for Refugees, who argued that the term "integration" is misleading because it does not give the right sense of the treatment accorded to refugees in the Sudan. He said,
If you talk of integration as a sort of naturalisation, this is completely rejected in the Sudan ... and I feel that refugees will not like it. Being a refugee in a country for 20, 30 or 100 years, I don't think will deprive you of your own nationality, your own origin... That is why in Sudan... this policy of local settlement, rather than local integration [is adopted]. ${ }^{22}$

Thus in Sudan as in many other developing societies, refugee camps and settlements are created as a means of preventing refugees from incorporating themselves into the larger society. The Commissioner for Refugees further maintained,

... refugees should be given a certain place [a camp or settlement] to continue their own sort of relations, with their own people [not with Sudanese], not to forget their country, because we are not interested that they will forget their countries, they have to go back. We don't want more population in this country: enough is enough. ${ }^{23}$

Camps and settlements are thus established to perpetuate, rather than to bring to an end, refugee status and to accomplish this by blocking the incorporation of refugees into host societies. In the government's view the best way to achieve this goal is to keep refugees in spatially segregated "containers" so that they are able to maintain their old relationship with each other in isolation from local populations and consequently maintain their collective national identity.

It is important to state that this is not only true in Sudan. It is generally true of all refugee-hosting countries in the developing societies. The statements of the Sudanese Commissioner for Refugees and the Assistant Commissioner accurately encapsulate the principles underlying nearly all government policies in the developing world. On paper, Tanzania made a general offer of naturalization to all refugees in 1980, but bureaucratic incompetence and the refugees' economic inability to meet prohibitive charges prevented many refugees from seizing the opportunity to be naturalized. ${ }^{24}$ However, during the Great Lake crisis in the mid-1990s, not only did Tanzania backtrack on naturalization, but it also closed its borders with Rwanda. The country's Foreign Minister said, "We are saying enough is enough. Let us tell the refugees that the time has come for them to return home and no more should come." ${ }^{25}$ The country also forcibly repatriated thousands of Rwandan refugees in 1996 in a situation where the political conditions were unsafe. In the 1980s, not only were Rwandan refugees forcibly repatriated from Uganda after having lived there for decades, but they were also victimized by Obote's government under which over 60,000 died in the Lwero triangle of Buganda. ${ }^{26}$ All the available studies show 
that in all developing countries, refugees are accepted as temporary guests and placement of refugees in spatially segregated rural sites is seen as an indispensable instrument of operationalizing such a policy. ${ }^{27} \mathrm{It}$ is also worth mentioning here that in sub-Saharan Africa, most international assistance is directed to refugee camps and formal settlements. ${ }^{28}$

\section{Minimization of Actual or Perceived Risk of National Security}

There is an excessive tendency on the part of host governments to label the presence of refugees, including immigrants, in their territories a security threat. The single most important reason why governments place refugee issues on the security agenda is to excuse even the most unjustifiable or draconian measures they take against them. Such measures are often justified in terms of the need to avert the danger that might occur in the absence of such measures. Security, Waever argues, is:

... a practice, a specific way of framing an issue. Security discourse is characterised by dramatising an issue as having absolute priority. Something is presented as an existential threat: if we do not tackle this, everything else will be irrelevant... And by labelling this a security issue, the actor has claimed the rights to deal with it by extra-ordinary means, to break the normal political rules of the game ... Something is presented as existentially threatened, and on this basis it is argued the 'we' must use extra-ordinary means to handle the threat. ${ }^{29}$

If a government places an issue on the security agenda, whatever measures it takes to avert the alleged danger are said to be dictated by necessity. Thus if refugees are considered to constitute a threat to national security, whatever measures governments take to protect themselves and their citizens against the alleged threat of insecurity, including their confinement in spatially segregated sites, are considered justifiable. The presence of Eritrean refugees in Sudan was, for example, securitized from the outset. ${ }^{30}$ The Sudanese government of the time even went to the extent of handing over to Ethiopia twelve prominent Eritreans in $1961 .^{31}$ The placement of refugees in spatially segregated sites is therefore designed to facilitate control of refugee movements and their activities. ${ }^{32}$ If refugees are allowed to settle freely among local populations, host governments often fear or pretend to fear that not only may they freely engage in subversive activities and threaten the security of receiving areas and their countries of origin, but also influence citizens by "contaminating" their political views. Thus, it is not uncommon for host governments to view refugees as potentially dangerous that could radicalize their citizens.
Hence their placement in spatially segregated sites is seen as a means of avoiding the danger of insecurity.

\section{Prevention of Competition for Resources and Services}

Spatial segregation enables governments to prevent refugees from competing with nationals for employment, land, water, pasture, firewood, construction materials, common property resources, employment, transportation, housing, and income-generating opportunities. Many developing countries have been facing shortages of such resources due to many reasons. For example, in Sudan, though over half of the total refugee population managed to avoid them, all refugees are by law required to reside in camps and settlements in accordance with government policy. Those who self-settle outside camps and settlements often face the risk of being rounded up, harassed, detained, and deported to rural areas. ${ }^{33}$ In some countries refugees found outside the designated areas are deported to their countries of origin even when the factors that prompted their flight are not eliminated. ${ }^{34}$

As we saw before, the rapid process of urbanization is taking place in all sub-Saharan Africa in the context of a stagnant manufacturing sector and over-saturated service and informal sectors. Unemployment in urban areas is rampant. Governments and host populations thus resent the presence of refugees because they are said to compete for scarce employment and self-employment opportunities. Though the economic crises facing African countries have nothing to do with the presence of refugees, the latter are invariably blamed for being the causes of economic crisis and of shortages of housing, transportation, water, electricity, employment, etc. Refugees are also blamed for theft, crimes, prostitution, and other forms of anti-social behaviour.

Ironically, the blame game has been exacerbated by multi-party elections that have been spreading over most sub-Saharan African countries since the end of the 1980s. This is contrary to expectations. In many countries, opportunist politicians use the refugee card to stir up xenophobic sentiments among their constituencies in order to win votes by blaming shortages of employment opportunities, resources, and services, as well as crimes, on refugees. In refugee-hosting countries, many parliamentary candidates promise to throw out refugees if they are elected. This is not only true in the developing countries but the refugee card is vote-winning even in "mature" democracies.

\section{Prevention of Ethnic Imbalance in Border Areas}

Colonial borders divide many ethnic groups, and governments fear that if refugees are allowed to self-settle among members of their own ethnic groups in border areas, the 
numerical sizes of some of the border communities would increase substantially. There is a concern on the part of governments that this might upset the pre-existing ethnic balance of power. In some cases, this imbalance could jeopardize the security and stability of local communities. Thus, governments opt for relocation of refugees to areas away from people with whom they share a common ethnicity. In Sudan this consideration has been the main factor as to why the authorities in the local government in the east were reluctant to accept the establishment of refugee settlements in Kassala Province.

The large majority of the Eritrean refugees who fled Eritrea in the second half of the 1960s were from the Beni Amer ethnic group. Having members of their ethnic group provided a soft landing in the border areas with Sudan. Because of pre-existing trade and other ties, they had longstanding social networks which they made use of in adversity and consequently found new homes among the border Sudanese communities.

However, the Beni Amer had a long-standing feud with another Sudanese border community, the Hadendowa. This feud degenerated into war in the early 1940s over grazing rights along the Eritrean frontier which the Beni Amer regarded as their own. A tense situation exploded in 1942 when a simple incident of a camel theft triggered a bloody tribal war which raged off and on for more than three years. ${ }^{35}$ Though a peace settlement was successfully negotiated in December 1945 in which the Beni Amer agreed to pay the Hadendowa thousands of pounds compensation and surrendered about 700 rifles $^{36}$ the relationship between the two tribes has always been tense.

When nearly 30,000 Eritrean Beni Amer refugees arrived in the border areas inhabited by Sudanese Beni Amer and the Hadendowa in February and March of 1967, the number of Sudanese Beni Amer increased dramatically not only in the rural border areas but also in the urban border town of Kassala. This created a sudden imbalance which the Sudanese authorities feared could encourage the Sudanese Beni Amer to attack their long-standing adversaries. Hence a decision was taken to relocate the Eritrean refugees far from the border areas to the district of Qala en Nahal which belonged to the Shukria tribe, but the particular sites where the refugees were settled were either empty or sparsely inhabited by West African immigrants. ${ }^{37}$

This is not only true in Sudan but is a common consideration in many refugee-hosting countries in Africa. For example, the Banyarwanda refugees were settled in the border areas of Uganda. In the early 1980s the refugees were attacked by Obete's government for their alleged support for Yoweri Museveni's resistance movement. As a result, thousands were killed and the survivors were either de- ported or scattered. Most African governments allege that the reason they reject self-settlement of refugees in both urban and rural areas is to avoid such dangers. Since such dangers are rare occurrences, governments use such incidents in attempts to justify their unjustifiable reception and settlement strategies.

\section{Shifting of Financial Responsibility to the International Donor Communities}

Refugees in segregated sites, besides being visible, can be kept as distinct groups indefinitely. If they are allowed to self-settle among local populations, they could easily melt into local communities and become indistinguishable. This among other things could weaken governments' requests for funds from donors. Thus, placement of refugees in spatially segregated sites is seen as a necessary condition for shifting the responsibility of meeting refugees' needs to the international donor community indefinitely. For example, some refugees in the developing countries have been living in refugee settlements and camps for over thirty years and, in most cases, the international donor community has been footing the bill for all this time. It is interesting to note in this connection that, as pointed out earlier, all international assistance is only channelled to those who are placed in spatially segregated sites-namely, camps and settlements. Those who are outside camps and settlements, particularly in the urban areas, receive no international or any form of assistance. Thus, governments have no incentive to allow refugees to settle themselves.

However, the reason why aid agencies are reluctant to provide assistance to urban refugees is because this would undermine host governments' policies and pull refugees to urban centres from rural refugee camps and settlements. As pointed out earlier, in Sudan, a large number of the Eritrean and Ethiopian refugees are settled in cities and towns in defiance of the government's policy. As a result they are subjected to periodic roundups, arbitrary detention, extortion, payment of bribes, etc. Those without transnational networks also suffer from lack of basic necessities such as food, clothing, and shelter. The UNHCR and the other aid agencies are aware of their plight but they argue they cannot help them because this would be contrary to the host government's policy. Hence the refugees have to either depend on remittances or fend for themselves by different means.

\section{Opportunities to Develop Previously Neglected Remote Areas}

The arrival of refugees in poor countries is invariably accompanied by provision of emergency relief provided the said refugees are placed in camps which, in sub-Saharan African countries, are invariably located in rural areas. In most 
refugee-hosting countries, assistance is seldom provided to refugees in urban areas. Egypt, South Africa, and to some extent Kenya are probably the exceptions.

Many countries in Africa, at least in the past, relocated refugees to self-sufficiency projects which are in most cases based in remote areas. UNHCR and other donor agencies often foot the bill for the development of the infrastructure, including roads. This benefits local communities and the government of the country concerned. For example, the refugee settlements located in remote areas in Tanzania produce large amounts of tobacco and food crops which contribute to the country's foreign exchange earnings and regional food security, respectively. The six refugee settlements in Qala en Nahal also used to produce substantial amounts of the cash crop sesame. Prior to the establishment of the Qala en Nahal refugee settlements, all the local populations used to migrate to the Rahad River during the dry season. When the refugee settlements were established, UNHCR with its partners established a reliable water supply system that enabled the local population to stay in their villages throughout the year. ${ }^{38}$ There is thus evidence to suggest that one of the reasons why governments do not want refugees in urban areas and prefer to place them in designated rural areas is to take advantage of UNHCR and donor resources to develop areas previously neglected areas due to lack of resources.

\section{Minimization of Perceived Societal Insecurity}

Societal security refers to "...the sustainability, within acceptable condition, of traditional patterns of language, culture and religious and national identity and custom." 39 It is often assumed that it is only refugees seeking asylum in the predominantly white societies of the North who experience racism and discrimination. There is evidence to show that even refugees who seek asylum in the South are sometimes regarded as "pollutants" of host countries' "cultural purity" 40 and civic virtues. For example, in Sudan municipality police in Khartoum wrote to the General Director of the Police stating: "We have been watching, with great alarm, the continuing refugee influx in Khartoum. Your Excellency will undoubtedly agree that such an unorganised movement will contribute to an increase in the rate of crime." 41 The Khartoum Police Commissioner in his recommendation to restrict the movement of refugees to the capital city wrote:

We write this in the hope that your Excellency will contact the competent authority and propose to the Minister of the Interior that he should use powers accorded to him by Article 10(2) of the Regulation of Asylum Act, to restrict the refugee movement from the camps. This will enable us to take the necessary measures to stop this harmful movement which is becoming a threat to our moral values and public decency. ${ }^{42}$

Anything that constitutes "a threat" to "moral values and public decency" by definition constitutes a threat to societal security, and one of the reasons why host governments are determined to remove refugees from urban areas and place them in camps and settlements is to "keep their cultural purity" intact (sic). The Sudanese police authorities and many nationals seem to regard the Eritrean and Ethiopian refugees' liberal lifestyles, particularly the relations between the two sexes, as a threat to societal security. These are seen as constituting a major threat to Sudanese religious and cultural norms, as well as way of life. The experience of refugees elsewhere, e.g. Tanzania, also shows that local hosts do not seem to attach the same value to refugees' lives and physical safety as they would to a citizen's. A Burundian refugee living in Kigoma (a Tanzanian town) told Lisa Malkki,

Apart from problems of food and lodging, the gravest problems were only that citizens considered us to be savage animals. I say this because sometimes, if one hits a Burundian, it was said, 'Hit harder, it is a refugee.' For this we found ourselves to be without value in their eyes. ${ }^{43}$

Though I have not conducted fieldwork in Egypt, a discussion I held with a group of Eritrean refugees in the American University in Cairo also showed that the host population and government officials regarded them as representing a threat to societal security. A few South Sudanese refugees I talked to in Alexandria and Cairo also confirmed this.

Throughout this article it has been demonstrated that local and national authorities of a range of African countries seek to segregate, control, and ignore the needs of refugees in their midst, as they are seen to compete with nationals for limited services while presenting a perceived threat to their hosts' security and way of life. It is argued that these underlying factors, plus the protracted problems for governments created by urbanization generally and cross-border ethnic solidarity in the case of many refugee movements in Africa, shape current hostile refugee policies towards urban refugees.

\section{Notes}

1. G. Kibreab, "Eritrean and Ethiopian Refugees in Khartoum: What the Eye Refuses to See," African Studies Review 39, no. 3 (1996): 131-78.

2. G. Kibreab, State Intervention and the Environment in Sudan 1889-1989: The Demise of Communal Resource Management 
(Lewiston, NY; Queenston, Ontario; and Lampeter, Wales: Edwin Mellen Press, 2002).

3. For an extensive discussion on refugee policies in selected countries in the less developed countries, see G. Kibreab, "Citizenship Rights and Repatriation of Refugees," International Migration Review 37, no. 1 (2003): 24-73. For Sudan's government policy on urban refugees, see G. Kibreab, "Eritrean and Ethiopian Refugees: What the Eye Refuses to See"; G. Kibreab, "Resistance, Displacement and Identity: The Case of Eritrean Refugees in Sudan," Canadian Journal of African Studies 34, no. 2 (2000):249-296; A. Karadawi, Refugee Policy in Sudan 1967-1984 (Oxford: Berghahn Books, 1999). For Central America, see E. Ferris, The Central American Refugees (New York: Praeger, 1987). For Tanzania, see B. Rutinwa, "Refugee Admission and Eligibility Procedures in Tanzania: The Law and Practice" (unpublished, Dar es Salaam, 2001); B. Rutinwa, "The Tanzanian Government's Response to the Rwandan Emergency," Journal of Refugee Studies 9, no. 3 (1996): 291-302.

4. See G. Kibreab, "Citizenship Rights and Repatriation of Refugees."

5. Ibid.

6. See G. Kibreab, "Eritrean and Ethiopian Refugees in Khartoum: What the Eye Refuses to See." See also M. Sommers, Fear in Bongoland: Burundi Refugees in Urban Tanzania (New York and Oxford: Berghahn Books, 2001).

7. South Africa and Egypt are the only exceptions. Once asylum seekers are granted refugee status, they are free to live in the urban centres of South Africa and Egypt. In other countries, refugee status is premised on residence in government-designated sites.

8. See A. Karadawi, Refugee Policy in Sudan 1967-1984; G. Kibreab, "Eritrean and Ethiopian Refugees in Khartoum: What the Eye Refuses to See."

9. L. Malkki, Purity and Exile: Violence, Memory and National Cosmology among the Hutu Refugees in Tanzania (Chicago: University of Chicago Press, 1995). See also G. Kibreab, Ready and Willing ... but Still Waiting: Eritrean Refugees in Sudan and the Dilemmas of Return (Uppsala: Institute of Life and Peace, 1996); G. Kibreab, "Resistance, Displacement and Identity."

10. G. Kibreab, "Citizenship Rights and Repatriation of Refugees."

11. Statute of UNHCR, Annex to Resolution 428(V) of the United Nations General Assembly.

12. G. Kibreab, "Citizenship Rights and Repatriation of Refugees."

13. Tanzania no longer pursues an open door policy. Its policy towards refugees has changed dramatically as a consequence of the refugee crisis in the Great Lake Region. For Tanzania, see B. Rutinwa, "Refugee Admission and Eligibility Procedures in Tanzania: The Law and Practice"; B. Rutinwa, "The Tanzanian Government's Response to the Rwandan Emergency." For Africa in general and Sudan in particular, see G. Kibreab, "The African Refugee Regime with Emphasis on Northeastern
Africa: The Emerging Issues," in Legitimate and Illegitimate Discrimination: New Directions in Migration, ed. H. Adelman (Toronto: York Lanes Press, 1995), 57-102; G. Kibreab, "The Problem of Refugees in the Sudan: Some Unresolved Issues," in African Refugees: Development Aid and Repatriation, ed. H. Adelman and J. Sorenson (Boulder: Westview Press, 1994), 43-88; G. Kibreab, "Local Settlements in Africa: A Misconceived Option?” Journal of Refugee Studies 2, no. 4 (1989): 468-90; G. Kibreab, "Citizenship Rights and Repatriation of Refugees."

14. National Committee for Aid to Refugees (NCAR) Documentation for the June 20-23 Conference, vols. 1-3 (Khartoum, 1980), vol. 2, p. 2.

15. G. Kibreab, "Access to Economic and Social Rights in First Countries of Asylum and Repatriation: A Case Study of Eritrean Refugees in Sudan," in Problematising Rights and Policies in Forced Displacement: Whose Needs Are Right?, ed. Katarzyna Grabska and Lyla Mehta (Hampshire: Palgrave Macmillan, forthcoming).

16. Ibid.

17. Government of Sudan, Regulation of the Asylum Act, 1974, Article 9.

18. Ibid., Article 10 (2).

19. G. Kibreab, "Eritrean and Ethiopian Refugees in Khartoum: What the Eye Refuses to See."

20. A. Karadawi, "The Dynamics of Policy Towards the Refugee Problem in Sudan" (paper for the conference Sudan After Nimeiri, School of Oriental and African Studies, London, September 1985).

21. In fact throughout most of his life he was a champion of the refugee cause. He was also one of the two committed academics who founded the Refugee Studies Programme (RSP), now Centre for Refugee Studies, at Oxford University.

22. Hasen Mussa Atiya, quoted in G. Kibreab, "Resistance, Displacement and Identity," 389.

23. Ibid.

24. C. Gasarisi, "Mass Naturalisation and Further Integration of Rwandese Refugees in Tanzania," Journal of Refugee Studies 3 , no. 2 (1990): 88-109.

25. Quoted in B. Rutinwa, "The Tanzanian Government's Response to the Rwandan Emergency," Journal of Refugee Studies 9, no. 3 (1996): 291-302; 295.

26. R. Van der Meeren, "Three Decades in Exile: Rwandan Refugees 1960-90," Journal of Refugee Studies 9, no. 3 (1996): 252-68.

27. For a detailed comparative study, see G. Kibreab, "Citizenship Rights and Repatriation of Refugees."

28. See G. Kibreab, "Local Settlements in Africa: A Misconceived Option;" W. Kok, "Self-Settled Refugees and the Socio-Economic Impact of Their Presence on Kassala, Eastern Sudan," Journal of Refugee Studies 4, no. 2 (1989): 419-40.

29. O. Waever quoted in G. Kibreab, "Resistance, Displacement and Identity," 271.

30. A. Karadawi, Refugee Policy in Sudan 1967-84; G. Kibreab, "Resistance, DiSplacement and Identity." 
31. See J. Markakis, National and Class Conflict in the Horn of Africa (Cambridge: Cambridge University Press, 1990); G. Kibreab, "Resistance, Displacement and Identity."

32. A. Karadawi, Refugee Policy in Sudan 1967-1984; G. Kibreab, "Refugees in Sudan: Unresolved Issues;" G. Kibreab, "The African Refugee Regime with Emphasis on Northeastern Africa: Emerging Issues."

33. See A. Karadawi, Refugee Policy in Sudan 1967-1984; G. Kibreab "Stranded Birds of Passage?: Eritrean and Ethiopian Refugees in Khartoum," Refuge 10, no. 4 (1992): 6-11.

34. For many such examples see G. Kibreab, "Citizenship Rights and Repatriation of Refugees."

35. G. K. N. Trevaskis, Eritrea: A Colony in Transition: 1941-52 (London, New York, and Toronto: Oxford University Press, 1960), 71 .

36. Ibid.

37. See G. Kibreab, People on the Edge in the Horn: Displacement, Land Use and Environment (Oxford: James Currey Publishers, 1996); G. Kibreab, Refugees and Development: The Case of Eritrean Refugees (Trenton, NJ: Red Sea Press, 1987).

38. G. Kibreab, Refugees and Development: The Case of Eritrean Refugees.

39. B. Buzan, People, States and Fear: An Agenda for International Security Studies in the Post-Cold War Era, $2^{\text {nd }}$ ed. (London: Pearson/Longman, 1991), 19.

40. See G. Kibreab, "Resistance, Displacement and Identity."

41. Provincial Commissioner for Police to Director of Police, 17 December 1977, quoted in A. Karadawi, Refugee Policy in Sudan 1967-1984, 102.

42. Ibid., 103 (emphasis added).

43. Quoted in G. Kibreab, "Revisiting the Debate on People, Place, Identity and Displacement," Journal of Refugee Studies 12, no. 4 (1999): 385-410, 395.
Professor Gaim Kibreab is director of the post-graduate program in refugee studies at London Southbank University. Dr. Kibreab's work has focused largely on Eritrea and the Sudan, including a recent book on state intervention and the environment in Sudan. 